\title{
The Rhizobium leguminosarum bv. viciae gInD gene, encoding a uridylyltransferase/ uridylyl-removing enzyme, is expressed in the root nodule but is not essential for nitrogen fixation
}

\author{
Andreas Schlüter, ${ }^{1} \dagger$ Michael Nöhlen, ${ }^{1}$ Maria Krämer, ${ }^{1}$ \\ Roberto Defez ${ }^{2}$ and Ursula B. Priefer ${ }^{1}$
}

Author for correspondence: Ursula B. Priefer. Tel: +4924180 6644. Fax: +49 2418888637. e-mail: priefer@bio1.rwth-aachen.de

\footnotetext{
1 Ökologie des Bodens, Botanisches Institut, RWTH Aachen, Worringerweg 1, 52056 Aachen, Germany

2 International Institute of Genetics and Biophysics CNR, Via Marconi 12, 80125 Napoli, Italy
}

\begin{abstract}
A Rhizobium leguminosarum bv. viciae VF39 gene (gInD) encoding the uridylyltransferase/uridylyl-removing enzyme, which constitutes the sensory component of the nitrogen regulation (ntr) system, was identified, cloned and characterized. The deduced amino acid sequence contains the conserved active site motif of the nucleotidyltransferase superfamily and is highly homologous to the $g \ln D$ gene products of other bacterial species. Downstream of the VF39 gInD resides an open reading frame with similarity to the Salmonella typhimurium virulence factor gene mviN. Mutation of the $g / n D$ gene abolished the ability to use nitrate as a sole nitrogen source but not glutamine. In addition, neither uridylylation of $P_{\|}$nor induction of the ntr-regulated gInII gene (encoding glutamine synthetase II) under ammonium deficiency could be observed in mutant strains. This strongly suggests that $g$ InD mutants harbour a permanently deuridylylated $P_{\mid 1}$ protein and as a consequence are unable to activate transcription from NtrC-dependent promoters. The gInD gene itself is expressed constitutively, irrespective of the nitrogen content of the medium. A functional GInD protein is not essential for nitrogen fixation in $R$.

leguminosarum bv. viciae, but in situ detection of glnD expression in the symbiotic and infection zone of the root nodule and quantitative measurements suggest that at least part of the ntr system functions in symbiosis. The results also indicate that the $\mathrm{N}$-terminal part of $\mathrm{GInD}$ is essential for the cell, as deletions in the $5^{\prime}$-region of the gene appear to be lethal and mutations possibly affecting the expression of the first half of the protein have a significant effect on the vitality of the mutant strain.
\end{abstract}

Keywords: nitrogen regulation, uridylyltransferase, $\mathrm{P}_{\mathrm{II}}$ uridylylation, glutamine synthetase, mviN

\section{INTRODUCTION}

The soil bacterium Rhizobium leguminosarum bv. viciae fixes dinitrogen in symbiosis with host plants belonging to the genera Pisum, Vicia, Lathyrus and Lens

†Present address: Lehrstuhl für Genetik, Universität Bielefeld, Postfach 1001 31, 33501 Bielefeld, Germany.

Abbreviation: GS, glutamine synthetase.

The GenBank accession number for the sequence reported in this paper is AF155830. (van Rhijn \& Vanderleyden, 1995). The symbiotic interaction is initiated by an exchange of specific signal molecules between the plant and the microsymbiont (the bacterium) and culminates in the formation of specialized plant organs called root nodules which are colonized by the rhizobia (Bladergroen \& Spaink, 1998; Lorkiewicz, 1997; Dénarié \& Debellé, 1996; Downie, 1994). Upon release into the plant cell, rhizobia differentiate into bacteroids in which the nitrogen fixation $(n i f / f i x)$ genes are induced under the control of the central nitrogen fixation regulatory gene 
nifA. It is generally accepted that during the onset of nitrogen fixation, the bacterial nitrogen metabolism changes from ammonium assimilation to ammonium export, which is a prerequisite for an effective symbiosis in which the plant benefits from the fixed nitrogen (Brown \& Dilworth, 1975; Glenn \& Dilworth, 1985; Udvardi \& Day, 1997).

Under free-living conditions, rhizobia assimilate ammonium by the glutamine synthetase (GS)/glutamate synthase (GOGAT: glutamine-oxoglutarate aminotransferase) pathway leading to the production of glutamate from ammonium and 2-oxoglutarate (Bravo \& Mora, 1988). R. leguminosarum possesses three GSs encoded by $g \ln A$ (GSI), $g \ln I I$ (GSII) and $g \ln T$ (GSIII) (Espin et al., 1994). GSI is homologous to GS from enteric bacteria and its enzymic activity is regulated by reversible adenylylation/deadenylylation (Filser et al., 1986; Colonna-Romano et al., 1987; Bravo \& Mora, 1988). GSII is similar to eukaryotic GSs and its expression is most probably turned off in symbiosis (Shatters et al., 1989). The function of GSIII is not quite clear in $R$. leguminosarum but for Sinorhizobium meliloti it is known that GSIII is not expressed when GSI and GSII are present (de Bruijn et al., 1989; Chiurazzi et al., 1992; Shatters et al., 1993). None of the GS isoenzymes plays an essential role in symbiosis.

Activity of GSI and synthesis of GSI and GSII are controlled by the global nitrogen regulation (ntr) system, which modulates nitrogen metabolism in response to the prevailing nitrogen source and the needs of the cell (Merrick \& Edwards, 1995). In enteric bacteria, this system is composed of four components: the GlnD protein (uridylyltransferase/uridylyl-removing enzyme, UTase/UR), the signal transduction protein $\mathrm{P}_{\mathrm{II}}$ (encoded by $g \ln B$ ) and the two-component regulatory system $\mathrm{NtrB} / \mathrm{NtrC}$ (Merrick \& Edwards, 1995; Magasanik, 1982; Adler et al., 1975; Mangum et al., 1973). The activity of the $\mathrm{P}_{\text {II }}$ protein is stimulated by glutamine and inhibited by 2-oxoglutarate (Engleman \& Francis, 1978). Under high concentrations of fixed nitrogen, $\mathrm{P}_{\mathrm{II}}$ activates an adenylyltransferase (ATase, encoded by the $g \ln E$ gene), which in turn inactivates GSI by adenylylation. At the same time, $\mathrm{P}_{\mathrm{II}}$ causes NtrB, a sensory histidine protein kinase, to dephosphorylate and thereby inactivate the corresponding response regulator NtrC. As a consequence, NtrC-dependent $\left(\sigma^{54}\right)$ promoters are switched off. Under glutamine-limiting conditions, $\mathrm{P}_{\mathrm{II}}$ is uridylylated by the $g \ln D$ gene product, which leads to deadenylylation (activation) of GSI by the ATase and to phosphorylation of NtrC by NtrB. $\mathrm{NtrC}-\mathrm{P}$ then stimulates transcription of NtrC-dependent promoters (Jiang et al., 1998a, b, c).

The NtrB/NtrC regulatory system has also been identified in R. leguminosarum (Moreno et al., 1992), where it is cotranscribed with an open reading frame of unknown function from two $-35 /-10$-like promoters (Patriarca et al., 1993). In bacteroids, transcription was found to be down-regulated (Patriarca et al., 1996). Expression of the $g \ln I I$ gene, which is preceded by a characteristic $\sigma^{54}$ - dependent promoter, is strictly regulated by $\mathrm{NtrB} / \mathrm{NtrC}$ (Patriarca et al., 1992) and most probably turned off in symbiosis (Shatters et al., 1989). It was shown that the $\mathrm{P}_{\mathrm{II}}$ protein, which is encoded upstream of $g \ln A$ (Chiurazzi \& Iaccarino, 1990), negatively controls the transcriptional activity of $\mathrm{NtrC}$ and that it is subject to uridylylation, suggesting the presence of a UTase/URactivity also in R. leguminosarum (Amar et al., 1994; Colonna-Romano et al., 1993).

Here we describe the identification and characterization of a R. leguminosarum bv. viciae gene $(g \ln D)$ encoding such a uridylyltransferase/uridylyl-removing enzyme. We constructed mutants and tested the function and expression of this gene under free-living and symbiotic conditions.

\section{METHODS}

Bacterial strains, plasmids and growth conditions. Bacterial strains and plasmids are listed in Table 1. Escherichia coli was grown at $37^{\circ} \mathrm{C}$ in Assay Broth No. 3 (Oxoid) supplemented as needed with antibiotics at the following final concentrations: tetracycline, $10 \mu \mathrm{g} \mathrm{ml}^{-1}$; gentamicin, $10 \mu \mathrm{g} \mathrm{ml}^{-1}$; ampicillin, $100 \mu \mathrm{g} \mathrm{ml}^{-1}$; kanamycin, $25 \mu \mathrm{g} \mathrm{ml}^{-1}$. Rhizobium strains were grown in TY medium (Beringer, 1974) or Rhizobium minimal medium (RMM) (Hooykaas et al., 1977) at $30^{\circ} \mathrm{C}$. When needed, antibiotics were added at the following concentrations: streptomycin, $400 \mu \mathrm{g} \mathrm{ml}^{-1}$; tetracycline, $10 \mu \mathrm{g} \mathrm{ml}^{-1}$; gentamicin, $30 \mu \mathrm{g} \mathrm{ml}^{-1}$; neomycin, $100 \mu \mathrm{g} \mathrm{ml}^{-1}$. $\mathrm{KNO}_{3}$, $\mathrm{NH}_{4} \mathrm{Cl}$ or glutamine was used as nitrogen source at a concentration of $1 \mathrm{~g} \mathrm{l}^{-1}$. Indicator medium for strains expressing an active $\beta$-galactosidase was supplemented with 40 $\mu \mathrm{g} \mathrm{X}-\mathrm{Gal} \mathrm{ml}{ }^{-1}$ (final concentration). $\beta$-Glucuronidase activity was detected on agar medium containing 5-bromo-4-chloro-3indolyl $\beta$-D-glucuronide at a final concentration of $40 \mu \mathrm{g} \mathrm{ml}^{-1}$.

Genetic methods. The protocols for mating experiments, mobilization of plasmids between E. coli and Rhizobium strains as well as for Tn5 mutagenesis were as previously described (Simon, 1984; Priefer, 1989).

Standard DNA techniques. Total DNA was isolated by the CTAB (cetyltrimethylammonium bromide) method described by K. Wilson in Ausubel et al. (1987). Plasmid DNA and DNA fragments were purified using the QIAprep Spin Miniprep kit (Qiagen) and the USBioclean kit (USB) containing a glass powder suspension according to the manufacturers' instructions. Restriction enzyme digestion, agarose gel electrophoresis, DNA cloning and transformations were carried out according to Maniatis et al. (1982). For hybridization, separated restriction fragments were transferred onto Qiabrane nylon membranes (Qiagen) by vacuum blotting (Pharmacia) and probes were labelled with digoxigenin-11UTP (DIG DNA Labelling kit; Boehringer). Detection of hybridizing bands was achieved using the DIG Nucleic Acid Detection kit (Boehringer) based on an enzyme-catalysed colour reaction.

Sequence analysis. Appropriate restriction sites within the glnD-containing region were used to clone 200-700 bp fragments into sequencing vectors pUC18/19, pUC57, pBluescript II KS and pK18/19mob. Sequencing of the resulting recombinant plasmids was done for both strands by the chaintermination method using IRD-700 or IRD-800 labelled standard primers (universe and reverse) according to the 
Table 1. Bacterial strains and plasmids

\begin{tabular}{|c|c|c|}
\hline Strain/plasmid & Relevant characteristics & Reference \\
\hline \multicolumn{3}{|l|}{ Strains } \\
\hline \multicolumn{3}{|l|}{ Escherichia coli } \\
\hline S17-1 & Modified RP4 plasmid integrated into the genome of E. coli $294 \mathrm{rec} A$ & Simon et al. (1983) \\
\hline JM83 & $\Delta$ (lac pro) thi $\phi 80 \mathrm{~d} l a c Z \Delta \mathrm{M} 15$ & Vieira \& Messing (1982) \\
\hline XL-1 Blue & $\begin{array}{l}\text { recA1 endA1 gyrA96 hsdR17 supE44 lac }\left[\mathrm{F}^{\prime} \text { proAB lacl }{ }^{\mathrm{q}} \mathrm{Z} \Delta \mathrm{M} 15 \mathrm{Tn} 10\right. \\
\left.\left(\text { (tet }^{\mathrm{r}}\right)\right] \text { thi }\end{array}$ & Bullock et al. (1987) \\
\hline $\mathrm{DH} 5 \alpha$ & $\begin{array}{l}\text { supE } 44 \Delta \text { lacU169 ( } \phi 80 \text { lacZ } \Delta \mathrm{M} 15) \text { hsdR17 recA endA1 gyrA96 thi-1 } \\
\text { relA1 }\end{array}$ & Hanahan (1983) \\
\hline \multicolumn{3}{|c|}{$\begin{array}{l}\text { Rhizobium leguminosarum } \\
\text { bv. viciae }\end{array}$} \\
\hline VF39 & Wild-type, $\mathrm{Sm}^{\mathrm{r}}$ & Priefer (1989) \\
\hline VF39-B1 & $g \ln D:: \operatorname{Tn} 5$ mutant, $\mathrm{Nm}^{\mathrm{r}}$ & This work \\
\hline VF39-BB1 & $g \ln D:: \mathrm{Nm}^{\mathrm{r}}(\leftarrow)^{*}$ mutant, $\mathrm{Nm}^{\mathrm{r}}$ & This work \\
\hline VF39-BB3 & $g \ln D:: \mathrm{Nm}^{\mathrm{r}}(\rightarrow)^{*}$ mutant, $\mathrm{Nm}^{\mathrm{r}}$ & This work \\
\hline VF39-C & fix $C:: \mathrm{Nm}^{\mathrm{r}}(\rightarrow)^{*}$ mutant, $\mathrm{Nm}^{\mathrm{r}}$ & This work \\
\hline LPR1105 & Wild-type & Hooykaas et al. (1977) \\
\hline BS11 & $g \ln B$ mutant, $\mathrm{Nm}^{\mathrm{r}}$ & Amar et al. (1994) \\
\hline \multicolumn{3}{|l|}{ Plasmids } \\
\hline pBluescript II KS & Cloning and sequencing vector, $\mathrm{Ap}^{\mathrm{r}}$ & Stratagene \\
\hline pUC18/19 & Cloning and sequencing vector, $\mathrm{Ap}^{\mathrm{r}}$ & Yanisch-Perron et al. (1985) \\
\hline pUC57 & Cloning and sequencing vector, $A \mathrm{p}^{\mathrm{r}}$ & $\begin{array}{l}\text { Markausakas \& Dreguniene, } \\
\text { Fermentas }\end{array}$ \\
\hline $\mathrm{pK} 18 / 19 \mathrm{mob}$ & pK18/19 derivative, $m o b, \mathrm{Km}^{\mathrm{r}}$ & Schäfer et al. (1994) \\
\hline pSUP202 & pBR325 derivative, $m o b, \mathrm{Tc}^{\mathrm{r}} \mathrm{Ap}^{\mathrm{r}} \mathrm{Cm}^{\mathrm{r}}$ & Simon et al. (1983) \\
\hline pSUP202-Gm & pSUP202 derivative, $\mathrm{Tc}^{\mathrm{r}} \mathrm{Gm}^{\mathrm{r}} \mathrm{Cm}^{\mathrm{r}}$ & Colonna-Romano et al. (1990) \\
\hline pAS269 & pSUP301 derivative, $m o b, \mathrm{Ap}^{\mathrm{r}} \mathrm{Cm}^{\mathrm{r}} \mathrm{Tc}^{\mathrm{r}}$ & Patschkowski et al. (1996) \\
\hline pSUP1021 & $\mathrm{Tn} 5$-carrier suicide vector, $m o b, \mathrm{Cm}^{\mathrm{r}} \mathrm{Tc}^{\mathrm{r}} \mathrm{Km}^{\mathrm{r}}$ & Simon et al. (1986) \\
\hline pBI221.1 & pUC19 derivative, gus A cassette & Jefferson (1987) \\
\hline pJP2 & Broad-host-range promoter probe vector, $\mathrm{Tc}^{\mathrm{r}}$ & J. Prell, RWTH Aachen \\
\hline pMK97.2B & pUC19 derivative, $7 \cdot 7 \mathrm{~kb}$ EcoRI fragment carrying ' $g \ln D:: T n 5, \mathrm{Ap}^{\mathrm{r}}$ & This work \\
\hline pUC57-5/6 & $\begin{array}{l}\text { pUC57 derivative, } 16 \mathrm{~kb} K p n \mathrm{I} \text { fragment carrying the } g \ln D-m v i \mathrm{~N}^{\prime} \text { region } \\
\text { (both orientations), } \mathrm{Ap}^{\mathrm{r}}\end{array}$ & This work \\
\hline pAS1298 & $\begin{array}{l}\text { pK19mob derivative, } 1 \cdot 2 \mathrm{~kb} \text { HindIII-EcoRI fragment carrying pglnD', } \\
\mathrm{Km}^{\mathrm{r}}\end{array}$ & This work \\
\hline pAS1098 & $\begin{array}{l}\text { pSUP202-Gm derivative, } 2346 \text { bp } S p h I-B g l I I \text { fragment carrying ' } g \ln D \text { ', } \\
\text { Gm }^{r}\end{array}$ & This work \\
\hline pNE1 & pK19mob derivative, $1041 \mathrm{bp}$ HindIII fragment carrying ' $g \ln D$ ', $\mathrm{Km}^{\mathrm{r}}$ & This work \\
\hline pNE3 & $\begin{array}{l}\text { pK19mob derivative, } 926 \text { bp BamHI-BglII fragment carrying ' } g \ln D \text { ', } \\
\mathrm{Km}^{\mathrm{r}}\end{array}$ & This work \\
\hline pAS1198-BB3 & pSUP202-Gm derivative, $g \ln D:: \mathrm{Nm}^{\mathrm{r}}(\rightarrow)^{*}, \mathrm{Gm}^{\mathrm{r}} \mathrm{Cm}^{\mathrm{r}}$ & This work \\
\hline pAS1198-BB1 & pSUP202-Gm derivative, $g \ln D:: \mathrm{Nm}^{\mathrm{r}}(\leftarrow)^{*}, \mathrm{Gm}^{\mathrm{r}} \mathrm{Cm}^{\mathrm{r}}$ & This work \\
\hline pAS1198-2 & pSUP202-Gm derivative, $g \ln D$ deletion/insertion, $\mathrm{Gm}^{\mathrm{r}} \mathrm{Cm}^{\mathrm{r}}$ & This work \\
\hline pAS1092 & pSUP202 derivative, fix $C:: \mathrm{Nm}^{\mathrm{r}}, \mathrm{Tc}^{\mathrm{r}} \mathrm{Nm}^{\mathrm{r}}$ & This work \\
\hline pAR36A & $g \operatorname{lnII-lacZ}$ transcriptional fusion, $\mathrm{Tc}^{\mathrm{r}}$ & Patriarca et al. (1992) \\
\hline pAS1299 & pJP2 derivative, $\mathrm{p} g \ln D-g u s A$ transcriptional reporter gene fusion, $\mathrm{Tc}^{\mathrm{r}}$ & This work \\
\hline
\end{tabular}

*Arrows denote the orientation of the neomycin-resistance gene cassette $\left(\mathrm{Nm}^{\mathrm{r}}\right)$ in relation to the corresponding gene.

instructions of a Thermo-Sequenase fluorescent-labelled primer cycle sequencing kit with 7-deaza-dGTP (Amersham Pharmacia Biotech). Extension products were separated and detected on a LI-COR 4200L DNA Sequencer. An IRD-700 labelled IS50 specific primer (5'-CGGGAAAGGTTCCGTTCAGGACG-3') was used to generate sequences adjacent to the Tn5 insertion. Sequence analysis and determination of the coding probability was done using the computer programs of
Staden (1986). The deduced amino acid sequences were compared to the protein database NCBI BLAST E-Mail Server (Altschul et al., 1990).

\section{Construction of mutant strains and recombinant plasmids}

Construction of $R$. leguminosarum bv. viciae VF39 glnD mutants. A 2346 bp SphI-BglII fragment carrying the $5^{\prime}$-part of the $R$. leguminosarum bv. viciae VF39 $g \ln D$ region was 

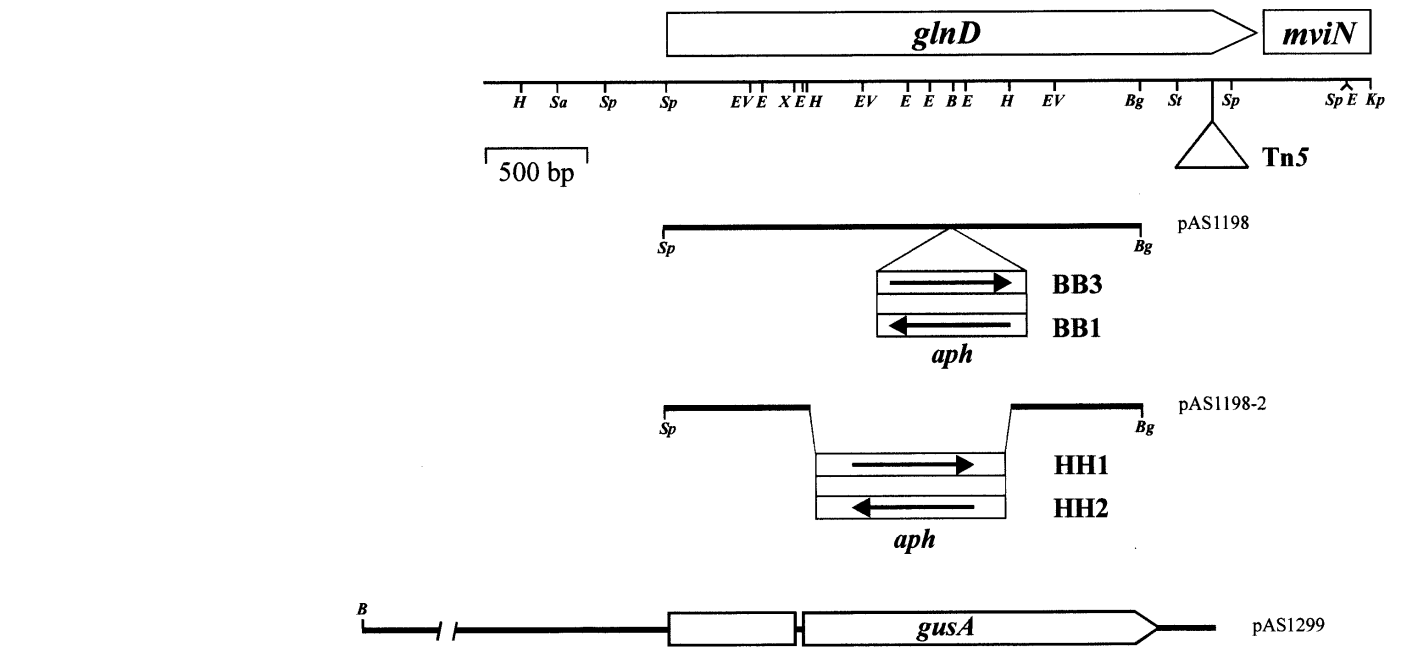

Fig. 1. Physical and genetic map of the $R$. leguminosarum bv. viciae VF39 glnD-mviN gene region. The $g / n D$ and $m v i N$ coding regions are indicated by arrows; only the $5^{\prime}$-end of the putative mviN gene is present on the cloned fragment. The location of the Tn5 insertion in the originally isolated $g / n D$ mutant is marked by a triangle. The Sphl-Bg/ll fragment cloned in plasmid pAS1198 was mutagenized by insertion of the neomycin-resistance gene cassette (aph aminoglycoside-phosphotransferase) in both orientations. The arrows indicate direction of transcription of the aph gene. The resulting plasmids pAS1198-BB3 and pAS1198-BB1 were used for the construction of $R$. leguminosarum bv. viciae $g \ln D$ insertion mutants. The fragment carried by pAS1198-2, in which the internal 1041 bp Hindlll fragment was replaced by a 3424 bp HindIII neomycin-resistance gene cassette and which did not yield any viable mutants, is also shown. pAS1299 is a mobilizable broad-host-range plasmid that carries a transcriptional glnD-gusA reporter gene fusion generated at the Xhol restriction site within $g \operatorname{lnD}$. B, BamHI; Bg, BgllI; E, EcoRI; EV, EcoRV; H, HindlII; Kp, Kpnl; Sa, Sacll; Sp, Sphl; St, Stul; X, Xhol. Only one Sacll site (upstream of $g \ln D$ ) is shown.

subcloned into the mobilizable plasmid pSUP202-Gm, resulting in plasmid pAS1098. A $1861 \mathrm{bp} \mathrm{HindIII-BamHI}$ fragment originating from Tn5 and carrying the neomycinresistance gene was converted into a BamHI fragment and subsequently cloned in both orientations into the single BamHI site in the centre of the $g \ln D$ gene (Fig. 1). The resulting constructs pAS1198-BB3 and pAS1198-BB1 were transferred from E. coli S17-1 to R. leguminosarum bv. viciae VF39 and recombined into the genomic $g \ln D$ region via double crossover. The corresponding mutants were designated VF39-BB3 and VF39-BB1 (Fig. 1). Correct homogenotization of the $g \ln D:: \mathrm{Nm}^{\mathrm{r}}$ mutation was verified by Southern hybridization analysis. For this purpose, total DNA restricted with $B g l \mathrm{II}$ and XhoI was hybridized using labelled pAS1099, which carries the almost complete $g \ln D$ gene on a $S p h \mathrm{I}$ fragment (Fig. 1). The wild-type DNA restricted with BglII showed two hybridizing bands of 4600 and $12000 \mathrm{bp}$; insertion of the 1881 bp neomycin-resistance cassette, which also carries a BglII site, into the $12000 \mathrm{bp} \mathrm{BglII}$ fragment resulted in two hybridizing bands (1266 and 12600 bp in VF39-BB1; 2467 and 11400 bp in VF39-BB3). Wild-type DNA restricted with XhoI showed two hybridizing bands of 4400 and $9000 \mathrm{bp}$. Insertion of the resistance cassette introduced another $\mathrm{XhoI}$ site into the 9000 bp fragment, yielding two bands in the mutant strains (1012 and $9900 \mathrm{bp}$ in VF39-BB1 and 2445 and $8400 \mathrm{bp}$ in VF39-BB3).

To construct a $g \ln D$ deletion/insertion mutant, an internal 1041 bp HindIII fragment was replaced by a 3423 bp HindIII neomycin-resistance cassette in plasmid pAS1098. The resulting plasmid pAS1198-2 (Fig. 1) was transferred to $R$. leguminosarum bv. viciae VF39 and exconjugants were selected on medium containing neomycin. In order to identify homogenotization events mediated by double crossover, about
2000 exconjugants were tested for loss of the plasmid-encoded gentamicin resistance. No such mutants could be obtained.

Construction of a $R$. leguminosarum bv. viciae VF39 fixC mutant. A 3400 bp Pst I-EcoRI fragment carrying the R. leguminosarum bv. viciae 'fixB-fixC-fixX-nifA' region was cloned into plasmid pSUP202. A 1900 bp BamHI neomycin-resistance gene cassette was then inserted into the single BglII site located in fixC. The resulting plasmid pAS1092 was mobilized into VF39 and the fixC:: $\mathrm{Nm}^{\mathrm{r}}$ mutation was homogenotized. The fixC mutant (VF39-C) was verified by Southern hybridization and by its complete inability to fix nitrogen.

Construction of a $R$. leguminosarum bv. viciae VF39 glnD-gusA reporter gene fusion. A $3500 \mathrm{bp} \mathrm{BamHI-XhoI} \mathrm{fragment} \mathrm{carry-}$ ing the $5^{\prime}$-end of the $g \ln D$ gene and the putative $g \ln D$ promoter region was cloned into the broad-host-range promoter probe vector $\mathrm{pJP}$, thus creating a transcriptional $\operatorname{pg} \ln D-g u s A$ reporter gene fusion at the Xhol site located $630 \mathrm{bp}$ downstream of the $g \ln D$ ATG start codon. The resulting plasmid was designated pAS1299 (Fig. 1).

Uridylylation of $\mathbf{P}_{\mathrm{II}}$. The assay for $\mathrm{P}_{\mathrm{II}}$ uridylylation was performed according to Colonna-Romano et al. (1993). Strains were grown in minimal media (RMM) containing glutamate as a nitrogen source. For every strain, three aliquots were taken in exponential growth phase, incubated for $2 \mathrm{~h}$ in 2 methyl-imidazole buffer containing $\left[\alpha^{32} \mathrm{P}\right] \mathrm{UTP} \quad(800 \mathrm{Ci}$ $\left.\mathrm{mM}^{-1} ; 29.6 \mathrm{TBq} \mathrm{mM}^{-1}\right)$, and subsequently either $30 \mu \mathrm{l} \mathrm{2-}$ oxoglutarate $(180 \mathrm{mM})$, glutamine $(200 \mathrm{mM})$ or water, respectively, was added to individual samples. All samples were incubated further for $2 \mathrm{~h}$ more and then analysed on a $15 \%$ SDS-PAGE gel. 
Enzyme tests. Quantitative determination of $\beta$-galactosidase activity was performed according to Miller (1972). The glnII promoter activity was tested by growing the strains first in rich medium (TY) and then transferring them into minimal medium with different nitrogen sources. Although the $g \ln D$ mutant strains are unable to use nitrate as sole nitrogen source, they still could reach exponential phase due to nitrogen carry-over from the rich medium. Exponential-phase cultures were taken for the assays. $\beta$-Glucuronidase activity was measured using the substrate $p$-nitrophenyl glucuronide (PNPG) as described by Jefferson (1987). $\beta$-Glucuronidase units were calculated according to Miller (1972). Determination of the $\beta$-glucuronidase activity of bacteroids was done by crushing nodules of about 10 plants in $1 \mathrm{ml} 50 \mathrm{mM}$ phosphate buffer with $10 \mu 110 \%$ Triton. Plant material was removed by centrifugation (5 min, 1000 r.p.m.). The supernatant was then centrifuged ( $5 \mathrm{~min}, 4500$ r.p.m.) to sediment the bacteroid fraction, which was suspended in $650 \mu \mathrm{l} 50 \mathrm{mM}$ phosphate buffer and used for PNPG tests.

Nodulation tests and determination of nitrogen fixation activity. Nodulation and nitrogen fixation tests using Vicia hirsuta as a host plant and acetylene reduction assays for the determination of nitrogenase activity were as previously described (Priefer, 1989).

GUS-specific staining of nodule sections. Nodules were excised from the roots of $V$. hirsuta plants $21 \mathrm{~d}$ after inoculation and embedded in $6 \%(\mathrm{w} / \mathrm{v})$ agarose in $50 \mathrm{mM}$ phosphate buffer. Sections of $90 \mu \mathrm{m}$ thickness were cut using a vibratome (VT 1000 S ; Leica). Nodule sections were stained as described previously (Schlüter et al., 1997).

\section{RESULTS AND DISCUSSION}

\section{Identification and cloning of the $R$. leguminosarum bv. viciae gInD gene}

For several Rhizobium species it has been shown that mutations in genes of the $n t r$ system cause defects in nitrate assimilation (Merrick \& Edwards, 1995). $R$. leguminosarum bv. viciae strain VF39 was mutagenized with transposon Tn5 using pSUP1021 as a suicide transposon carrier and Tn5-containing exconjugants were screened for growth on minimal medium (RMM) with different nitrogen sources. Two mutants out of approximately 10000 were identified to be unable to utilize nitrate but grew normally on RMM containing either ammonium or glutamine.

One of these mutants, designated VF39-B1, was characterized in more detail. A $7700 \mathrm{bp}$ EcoRI fragment containing the $\operatorname{Tn} 5$ insertion was cloned from the mutant genome taking advantage of the Tn5-encoded neomycin resistance. Partial sequencing of the cloned fragment using IS50-specific primers revealed that the transposon was inserted in a gene that showed considerable similarity to the glnD genes of Rhizobium tropici, Azotobacter vinelandii, Klebsiella pneumoniae and E. coli (O'Connell et al., 1998; Contreras et al., 1991; Edwards \& Merrick, 1995; van Heeswijk et al., 1993). Therefore, the corresponding $R$. leguminosarum bv. viciae gene was designated $g \ln D$.

The observed phenotype of VF39-B1 is consistent with Rhizobium mutants described in the literature: a $R$. tropici glnD mutant similarly fails to grow on nitrate as a sole nitrogen source (O'Connell et al., 1998), and a mutation in the R. leguminosarum bv. viciae glnB gene (encoding $\mathrm{P}_{\mathrm{II}}$, the target protein of $\mathrm{Gln} \mathrm{D}$ activity) also abolishes the ability to utilize nitrate (Amar et al., 1994). Glutamine prototrophy of the $g \ln D$ mutant can be explained by the fact that the $g \ln A$ gene (encoding GSI) is not strictly $n t r$-regulated since it contains in addition to the NtrC-dependent promoter a $-35 /-10$-like promoter sequence in its upstream region (Chiurazzi \& Iaccarino, 1990).

\section{Sequence analysis of the $R$. leguminosarum bv. viciae gln $D$ gene}

The Tn5 insertion was mapped precisely by sequencing and found to be located in the outermost 3 -end of the gene, only $197 \mathrm{bp}$ upstream of the stop codon (Fig. 1). Hybridization with the wild-type genome, using the Tn5-containing fragment as a probe, identified a $16 \mathrm{~kb}$ $K p n I$ fragment, which was isolated from the gel and cloned. Comparison of restriction analysis data of the cloned $16 \mathrm{~kb} K p n \mathrm{I}$ fragment with hybridization data obtained from probing the genomic $R$. leguminosarum bv. viciae $g \ln D$ region verified that the cloned fragment was native and originated from this organism. The Tn5containing EcoRI fragment cloned initially was shown to map at one end of the KpnI clone (Fig. 1).

Appropriate subclones of the $g \ln D$-containing region on the $16 \mathrm{~kb} \mathrm{KpnI}$ fragment were generated and sequenced. A 4087 bp DNA sequence starting at a SacII site located upstream of $g \ln D$ and ending at the $K p n \mathrm{I}$ site, marking one boundary of the cloned KpnI fragment (Fig. 1), is available under the GenBank accession number AF155830.

The R. leguminosarum bv. viciae glnD gene was found to be 2904 bp long and encoded a gene product of 968 amino acids with a calculated size of $108 \cdot 8 \mathrm{kDa}$ and an isoelectric point $(\mathrm{pI})$ of 6.9 . The deduced amino acid sequence showed $78 \%$ identity and $85 \%$ similarity to GlnD of R. tropici (O'Connell et al., 1998), and 30-31\% identity and $46-47 \%$ similarity to both GlnD of $K$. pneumoniae (Edwards \& Merrick, 1995) and to the $n f r X$ (a $g \ln D$ homologous gene) gene product of $A$. vinelandii (Contreras et al., 1991). The nucleotidyltransferase-superfamily motif (AVGGYGR-X $\mathrm{X}_{2}$-L-X-P$\mathrm{X}$-SDIDLL) suggested to be the active site of GlnD and to be involved in forming a so-called phosphate-binding loop (Holm \& Sander, 1995) was found to be conserved in all $g \ln D$ gene products compared (position 124-142 in the Rl-GlnD amino acid sequence). The region identified in NfrX which is homologous to a conserved stretch of amino acids in various GS proteins (Contreras et al., 1991) could not be detected in R. leguminosarum bv. viciae and R. tropici GlnD.

Downstream of $g \ln D$, a second incomplete ORF was identified which shows $91 \%$ identity and $95 \%$ similarity at the amino acid level to the N-terminus of R. tropici MviN and also $42 \%$ identity and $61 \%$ similarity to the 
virulence factors MviN of Salmonella typhimurium (SWISS-PROT accession no. P37169) and E. coli (GenBank accession no. for the gene product is AAC74153). Therefore this gene was tentatively designated mviN. In R. tropici, the mviN start codon overlaps the $g \ln D$ stop codon (-ATGA-, start/opal stop signal), whereas in R. leguminosarum both genes are separated by 52 nucleotides. A transcriptional terminator structure could not be found in this intergenic region but the sequence motif-ACGCATGAGCC-, which contains the overlapping start/opal stop signal -ATGA-, is repeated four times. The sequenced region extends $551 \mathrm{bp}$ upstream of $g \ln D$ but no obvious promoter structure could be detected by comparison to known $\sigma^{70}$ or $\sigma^{54}$ dependent promoters.

\section{Construction and phenotypic characterization of $R$. leguminosarum bv. viciae gInD mutants}

GlnD mutations described for A. vinelandii, E. coli and $R$. tropici map very close to the 3 '-end of the gene (Contreras et al., 1991; O'Connell et al., 1998; van Heeswijk et al., 1992), which is also true for the Tn5induced mutant isolated in this study (see above and Fig. 1). This led us to the assumption that mutations in the $5^{\prime}$-region of $g \ln D$ might be lethal and we therefore tried to introduce mutations in the central and $5^{\prime}$-part of the gene by site-directed mutagenesis. A neomycin-resistance cassette was cloned in both orientations into the central BamHI site (located 1418 bp downstream of the $\operatorname{gln} D$ start codon; Fig. 1) and the mutations could be easily integrated into the VF39 genome via homologous recombination. Correct homogenotization was verified by hybridization (for details see Methods) and the mutant strains were designated VF39-BB1 and VF39BB3.

We also tried to construct a $R$. leguminosarum bv. viciae $g \ln D$ deletion/insertion mutant by replacing an internal 1041 bp HindIII fragment with a HindIII neomycinresistance gene cassette (Fig. 1). Several attempts to homogenotize this construct failed (for details see Methods), which supports the hypothesis that mutations close to the $5^{\prime}$-end of the $g \ln D$ gene might be lethal.

Both mutant strains VF39-BB1 and VF39-BB3 were tested for their growth on RMM containing various nitrogen sources. As expected, none of the mutants could grow on nitrate. VF39-BB3 grew normally on ammonium and glutamine, whereas VF39-BB1 showed reduced growth rates with these nitrogen sources and even on rich medium (TY) its generation time was doubled (with and without neomycin) as compared to wild-type. This defect is probably not caused by a polar effect of the resistance cassette on the downstream $m v i N$-like gene since the mutation can be complemented by the original KpnI fragment, which contains the complete $g \ln D$ and only the $5^{\prime}$-part of $m v i N$ (Fig. 1). Moreover, the mviN gene in R. tropici was found to be involved in motility (O'Connell et al., 1998). We therefore assume that the reduced growth of VF39-BB1

\section{$\begin{array}{llllllllllll}1 & 2 & 3 & 4 & 5 & 6 & 7 & 8 & 9 & 10 & 11 & 12\end{array}$}

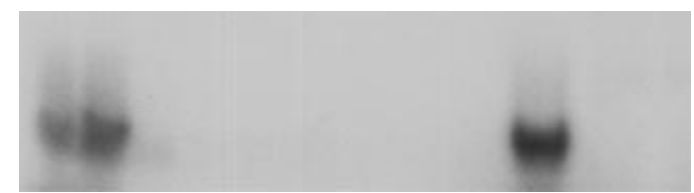

Fig. 2. Autoradiograph of the $P_{\| \mid}$uridylylation assay. Strains VF39 wild-type (lanes 1, 2 and 3), glnD mutant VF39-BB1 (lanes 4, 5 and 6), gInD mutant VF39-BB3 (lanes 7, 8 and 9), LPR1105 (lane 10) and $g \ln B$ mutant B11 (lanes 11 and 12) were grown in minimal medium containing glutamate and incubated with radioactively labelled UTP for $2 \mathrm{~h}$. Then, either water (lanes 1 , 4, 7, 10 and 11), 2-oxoglutarate (lanes 2, 5, 8 and 12) or glutamine (lanes 3, 6 and 9) was added.

is due to an antisense transcript initiated at the neomycin-resistance promoter and interfering at least partially with the $g \ln D$ mRNA 5 '-region, which gives further evidence for the assumption that the $\mathrm{N}$-terminal part of GlnD might be essential for viability.

The $g \ln D$ insertion mutants were also tested for their symbiotic performance on V. hirsuta plants. VF39-BB3 induced nodules which could not be distinguished from those elicited by the wild-type strain. Also plant growth and appearance were normal and nitrogenase activity was unaffected, which is in agreement with data published for the R. tropici glnD mutant (O'Connell et al., 1998). In contrast, mutant VF39-BB1 was significantly altered in its nodulation ability: only $8 \%$ of the plants were nodulated and the number of nodules per plant was reduced to $30 \%$ of the number formed by the wild-type strain. Nitrogen fixation activity, however, appeared to be unaffected as those few nodules fixed normally. Recovery of bacteria from the nodules confirmed that they still contained the $g \ln D$ mutation. Currently it is unclear whether the low nodulation efficiency of this strain is due to the mutated $g \ln D$ gene per se or a secondary effect of its reduced vitality.

\section{Effect of $g / n D$ mutations on $\mathrm{P}_{||}$uridylylation and $g / n I I$ expression}

Mutations in $g \ln D$ should affect uridylylation of the $\mathrm{P}_{\mathrm{II}}$ protein. We therefore analysed the ability of the glnD insertion mutants VF39-BB1 and VF39-BB3 to uridylylate $\mathrm{P}_{I I}$ under appropriate conditions (see Methods). As controls, we included the R. leguminosarum bv. viciae glnB mutant described by Amar et al. (1994), and the corresponding isogenic wild-type strain LPR1105. As shown in Fig. 2, a single protein with a molecular mass of $11 \mathrm{kDa}$ is labelled in the wild-type control strain (lane 10) and absent in the $g \ln B$ mutant (lanes 11 and 12). The same band is present in VF39 wild-type cells grown in minimal medium plus glutamate (lane 1). Labelling is further increased by addition of 2-oxoglutarate (lane 2) and decreased in the presence of glutamine (lane 3). This is in agreement with the reported sensitivity of $\mathrm{P}_{\mathrm{II}}$ uridylylation to the 
Table 2. Expression of the $g \ln D-g u s A$ reporter gene fusion on plasmid pAS1299 in $R$. leguminosarum bv. viciae under free-living and symbiotic conditions

Values are $\beta$-glucuronidase activity in Miller units and represent the mean of three independent measurements; numbers in parentheses give the standard deviations. NT, Not tested.

\begin{tabular}{|llccccc|}
\hline Strain & \multicolumn{1}{c}{ Characteristics } & TY & $\begin{array}{c}\mathbf{R M M}^{-} \\
\mathbf{N O}_{3}^{-}\end{array}$ & $\begin{array}{c}\text { RMM- } \\
\mathbf{N H}_{4}^{+}\end{array}$ & $\begin{array}{c}\text { RMM- } \\
\text { Gln }\end{array}$ & Nodule \\
\hline VF39(pJP2)* & Wild-type & $4 \cdot 1(1 \cdot 7)$ & $7 \cdot 7(2 \cdot 2)$ & $8 \cdot 2(2 \cdot 8)$ & $4 \cdot 3(1 \cdot 4)$ & $2(0 \cdot 4)$ \\
VF39(pAS1299) & glnD-gusA & $414(12)$ & $427(15)$ & $403(16)$ & $465(10)$ & $157(29)$ \\
VF39-C(pAS1299) & fixC::Nm glnD-gusA & NT & NT & NT & NT & $209(24)$ \\
\hline
\end{tabular}

* pJP is the basic replicon of pAS1299.

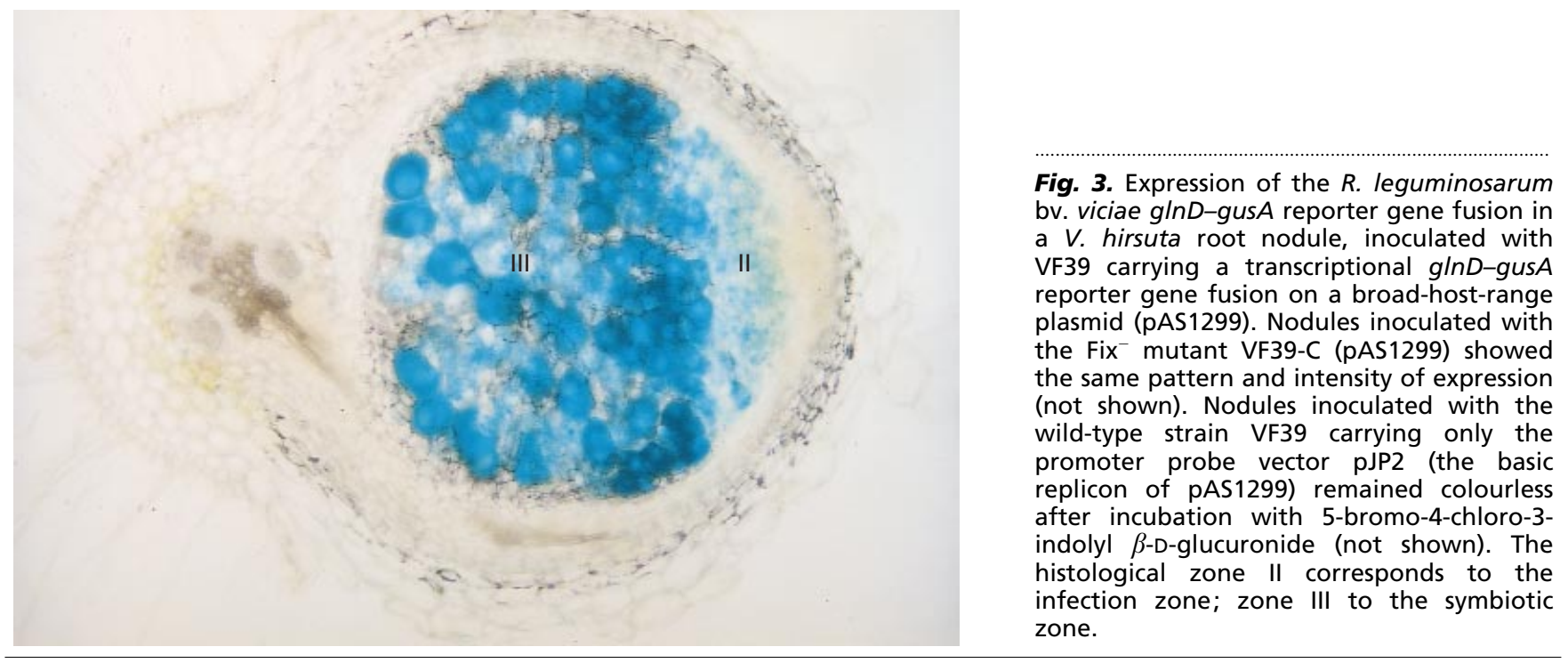

glutamine/2-oxoglutarate ratio (Adler et al., 1975). No labelling at all was observed in the glnD mutants VF39BB1 and VF39-BB3 (lanes 4-9), suggesting that both mutant GlnD proteins had lost their uridylylation activity, leading to a constitutively deuridylylated $\mathrm{P}_{\text {II }}$ protein.

To analyse the effect of a $g \ln D$ mutation on $\mathrm{NtrC}$ activity, we tested activation of the glnII gene, encoding GSII, the expression of which is under strict $n t r$ control (Patriarca et al., 1992). Plasmid pAR36A carrying a glnII-lacZ reporter gene fusion was introduced into the VF39 wild-type strain and into mutant VF39-BB3. Recombinant Rhizobium strains were first grown in TY rich medium, then incubated in RMM containing either nitrate or ammonium (for details see Methods), and exponential-phase cultures were measured for their $\beta$ galactosidase activities in three independent assays. Whereas in wild-type the $g \ln I I$ fusion was induced by a factor of about $3 \cdot 4$ in medium containing nitrate $(83 \pm 7$ Miller units in $\mathrm{RMM}-\mathrm{NH}_{4}^{+}$and $284 \pm 29$ Miller units in $\mathrm{RMM}-\mathrm{NO}_{3}^{-}$), this induction was abolished in the $g \ln D$ mutant strain VF39-BB3 $(79 \pm 7$ and $83 \pm 9$, respectively). In contrast, a $R$. leguminosarum bv. viciae glnB mutant shows constitutive expression of $g \ln I I$ as shown by Amar et al. (1994). The authors proposed that the $g \ln B$ gene product, $\mathrm{P}_{\mathrm{II}}$, plays a negative role in the ability of NtrC to activate transcription, probably because it activates NtrB-mediated dephosphorylation of NtrC-P. This dephosphorylation would not take place in the $g \ln B$ mutant, thus leaving NtrC-P in its active form. Accordingly, in a $g \ln D$ mutant, in which $\mathrm{P}_{\mathrm{II}}$ obviously exists in its deuridylylated form, NtrC is most probably permanently dephosphorylated and thus no longer able to activate transcription at $n t r$-dependent promoters.

\section{Expression of glnD under free-living and symbiotic conditions}

To analyse the expression of the R. leguminosarum bv. viciae $g \ln D$ gene, a transcriptional $g \ln D-g u s A$ reporter gene fusion was constructed using a Xhol site located $630 \mathrm{bp}$ downstream of the $g \ln D$ start codon (Fig. 1). 
This fusion, carried on a mobilizable broad-host-range plasmid, was transferred to wild-type VF39 and its expression was tested in rich medium and in minimal medium containing nitrate, ammonium or glutamine as a nitrogen source. It was found that $g \ln D$ is constitutively expressed irrespective of the nitrogen source (Table 2), which is consistent with the presumption that $\mathrm{G} \operatorname{lnD}$ itself is the nitrogen-sensing component. This most probably occurs by a mechanism that modulates its activity in response to nitrogen availability, as suggested by Jiang et al. (1998a). Nitrogen-independent constitutive expression was also shown for the E. coli glnD gene (van Heeswijk et al., 1993; Kim et al., 1998), whereas in $R$. tropici expression of a transcriptional glnD-gusA fusion could not be detected at all (O’Connell et al., 1998).

Since we had shown that a functional $g \ln D$ gene is not essential for nitrogen fixation (see above), it was interesting to see whether $g \ln D$ is expressed at all in symbiosis or switched off. As demonstrated in Fig. 3, expression of the $g \ln D-g u s A$ fusion was found throughout the entire symbiotic zone (zone III) of the root nodule and was also visible in the infection zone (zone II). This could be confirmed by quantitative measurements (Table 2). To test whether the nitrogen status of the bacteroids influences $g \ln D$ expression, a fix $\mathrm{C} \mathrm{mu-}$ tant, which displays a strict Fix $^{-}$phenotype, was included in this study and the same pattern of expression was detected (data not shown). This demonstrates that the symbiotic expression of $g \ln D$ is not dependent on nitrogen fixation activity and thus most probably independent of the nitrogen status also in symbiosis.

At present, we can only speculate about the function of $g \ln D$ expression in symbiosis. Since $g \ln I I$ (GSII) is switched off in the root nodule, GSI is probably the only glutamine synthetase present in bacteroids (Shatters et al., 1989; Patriarca et al., 1992; Amar et al., 1994; Espin et al., 1994). Therefore, one could hypothesize that GlnD could play a role in the regulation pathway leading to GSI adenylylation, i.e. inactivation in symbiosis. However, for S. meliloti it was reported that GSI adenylylation is not essential for an effective symbiosis (Arcondeguy et al., 1996). On the other hand, it has been shown that Medicago sativa plants inoculated with a $S$. meliloti mutant unable to synthesize $\mathrm{G} \ln \mathrm{B}\left(\mathrm{P}_{\mathrm{II}}\right)$ are nitrogen-starved and the same effect was also observed with a mutated $g \ln B$ gene encoding a $\mathrm{P}_{\mathrm{II}}$ protein that could no longer be uridylylated (Arcondeguy et al., 1997). Therefore, in this system, expression and uridylylation of $\mathrm{P}_{\mathrm{II}}$ by the GlnD protein is required for the establishment of a functional symbiosis. Such nitrogen starvation symptoms were not observed for $V$. hirsuta plants inoculated with the R. leguminosarum bv. viciae $g \ln D$ mutant (this work), but in contrast to what was previously published by Amar et al. (1994), the $R$. leguminosarum bv. viciae glnB mutant shows only a $10 \%$ residual nitrogen fixation activity (R. Defez, unpublished results). Therefore, the role of the $R$. leguminosarum bv. viciae $\mathrm{G} \ln \mathrm{B}$ and $\mathrm{G} \ln \mathrm{D}$ proteins in symbiosis remains unclear and future work is needed to elucidate the nitrogen regulation pathway operating under symbiotic conditions.

\section{ACKNOWLEDGEMENTS}

We thank Bert Boesten for measuring glnII expression in the $g \ln D$ mutant strain. We also thank Nico Esser for cloning $g \ln D$ subfragments into sequencing vectors and Lars Giesen for technical help with sequencing on the LI-COR sequencer. Bob Kosier is acknowledged for editorial help. This work was supported by a grant from the European Community (BIO4CT97-2319).

\section{REFERENCES}

Adler, S. P., Purich, D. \& Stadtman, E. R. (1975). Cascade control of Escherichia coli glutamine synthetase. Properties of the $\mathrm{P}_{\mathrm{II}}$ regulatory protein and the uridylyltransferase-uridylyl-removing enzyme. J Biol Chem 250, 6264-6272.

Altschul, S. F., Gish, W., Miller, W., Myers, E. W. \& Lipman, D. J. (1990). Basic local alignment search tool. J Mol Biol 215, 403-410.

Amar, M., Patriarca, E. J., Manco, G., Bernard, P., Riccio, A., Lamberti, A., Defez, R. \& laccarino, M. (1994). Regulation of nitrogen metabolism is altered in a $g \ln B$ mutant strain of Rhizobium leguminosarum. Mol Microbiol 11, 685-693.

Arcondeguy, T., Huez, I., Fourment, J. \& Kahn, D. (1996). Symbiotic nitrogen fixation does not require adenylylation of glutamine synthetase I in Rhizobium meliloti. FEMS Microbiol Lett 145, 33-40.

Arcondeguy, T., Huez, I., Tillard, P., Gangneux, C., de Billy, F., Gojon, A., Truchet, G. \& Kahn, D. (1997). The Rhizobium meliloti PII protein, which controls bacterial nitrogen metabolism, affects alfalfa nodule development. Genes Dev 11, 1194-1206.

Ausubel, F. M., Brent, R. \& Kingston, R. (editors) (1987). Current Protocols in Molecular Biology. New York: Wiley.

Beringer, J. E. (1974). R factor transfer in Rhizobium leguminosarum. J Gen Microbiol 84, 188-198.

Bladergroen, M. R. \& Spaink, H. P. (1998). Genes and signal molecules involved in the rhizobia-leguminoseae symbiosis. Curr Opin Plant Biol 1, 353-359.

Bravo, A. \& Mora, J. (1988). Ammonium assimilation in Rhizobium phaseoli by the glutamine synthetase-glutamate synthase pathway. J Bacteriol 170, 980-984.

Brown, C. M. \& Dilworth, M. J. (1975). Ammonia assimilation by Rhizobium cultures and bacteroids. J Gen Microbiol 86, 39-48.

de Bruijn, F. J., Rossbach, S., Schneider, M., Ratet, P., Messmer, S., Szeto, W. W., Ausubel, F. M. \& Schell, J. (1989). Rhizobium meliloti 1021 has three differentially regulated loci involved in glutamine biosynthesis, none of which is essential for symbiotic nitrogen fixation. J Bacteriol 171, 1673-1682.

Bullock, J. C., Fernandez, J. M. \& Short, J. M. (1987). XL1Blue: a high efficiency plasmid transforming recA Escherichia coli strain with $\beta$-galactosidase selection. BioTechniques 5, 376-379.

Chiurazzi, M. \& laccarino, M. (1990). Transcriptional analysis of the $g \ln B-g \ln A$ region of Rhizobium leguminosarum biovar viciae. Mol Microbiol 4, 1727-1735.

Chiurazzi, M., Meza, R., Lara, M., Lahm, A., Defez, R., laccarino, M. \& Espin, G. (1992). The Rhizobium leguminosarum biovar phaseoli gln $T$ gene, encoding glutamine synthetase III. Gene 119, $1-8$.

Colonna-Romano, S., Riccio, A., Guida, M., Defez, R., Lamberti, A., laccarino, M., Arnold, W., Priefer, U. \& Pühler, A. (1987). Tight 
linkage of $g \ln A$ and a putative regulatory gene in Rhizobium leguminosarum. Nucleic Acids Res 15, 1951-1964.

Colonna-Romano, S., Arnold, W., Schlüter, A., Boistard, P., Pühler, A. \& Priefer, U. B. (1990). An Fnr-like protein encoded in Rhizobium leguminosarum biovar viciae shows structural and functional homology to Rhizobium meliloti FixK. Mol Gen Genet 223, 138-147.

Colonna-Romano, S., Patriarca, E. J., Amar, M., Bernard, P., Manco, G., Lamberti, A., laccarino, M. \& Defez, R. (1993). Uridylylation of the $\mathrm{P}_{\mathrm{H}}$ protein in Rhizobium leguminosarum. FEBS Lett 330, 95-98.

Contreras, A., Drummond, M., Bali, A., Blanco, G., Garcia, E., Bush, G., Kennedy, C. \& Merrick, M. (1991). The product of the nitrogen fixation regulatory gene $n f r X$ of Azotobacter vinelandii is functionally and structurally homologous to the uridylyltransferase encoded by $g \ln D$ in enteric bacteria. $J$ Bacteriol 173, 7741-7749.

Dénarié, J. \& Debellé, F. (1996). Rhizobium lipo-chitooligosaccharide nodulation factors: signaling molecules mediating recognition and morphogenesis. Annu Rev Biochem 65, 503-535.

Downie, J. A. (1994). Signalling strategies for nodulation of legumes by rhizobia. Trends Microbiol 2, 318-324.

Edwards, R. \& Merrick, M. (1995). The role of uridylyltransferase in the control of Klebsiella pneumoniae nif gene regulation. Mol Gen Genet 247, 189-198.

Engleman, E. G. \& Francis, S. H. (1978). Cascade control of E. coli glutamine synthetase. II. Metabolite regulation of the enzymes in the cascade. Arch Biochem Biophys 191, 602-612.

Espin, G., Moreno, S. \& Guzman, J. (1994). Molecular genetics of the glutamine synthetases in Rhizobium species. Crit Rev Microbiol 20, 117-123.

Filser, D. M., Moscatelli, C., Lamberti, A., Vincze, E., Guida, M., Salzano, G. \& laccarino, M. (1986). Characterization and cloning of two Rhizobium leguminosarum genes coding for glutamine synthetase activities. J Gen Microbiol 132, 2561-2569.

Glenn, A. R. \& Dilworth, M. J. (1985). Ammonia movements in rhizobia. Microbiol Sci 2, 161-162, 165-167.

Hanahan, D. (1983). Studies on transformation of Escherichia coli with plasmids. J Mol Biol 166, 557-580.

van Heeswijk, W., Kuppinger, O., Merrick, M. \& Kahn, D. (1992). Localization of the $g \ln D$ gene on a revised map of the 200 kilobase region of the Escherichia coli chromosome. J Bacteriol 174, 1702-1703.

van Heeswijk, W. C., Rabenberg, M., Westerhoff, H. V. \& Kahn, D. (1993). The genes of the glutamine synthetase adenylylation cascade are not regulated by nitrogen in Escherichia coli. Mol Microbiol 9, 443-457.

Holm, L. \& Sander, C. (1995). DNA polymerase $\beta$ belongs to an ancient nucleotidyltransferase superfamily. Trends Biochem Sci 20, 345-347.

Hooykaas, P. J. J., Clapwijk, P. M., Nuti, M. P., Shilperoort, R. A. \& Roersch, A. (1977). Transfer of the Agrobacterium tumefaciens T1 plasmid to avirulent Agrobacteria and to Rhizobium explanta. J Gen Microbiol 98, 477-484.

Jefferson, R. A. (1987). Assaying chimeric genes in plants: the GUS fusion system. Plant Mol Biol Reporter 5, 387-405.

Jiang, P., Peliska, J. A. \& Ninfa, A. J. (1998a). Enzymological characterization of the signal-transducing uridylyltransferase/ uridylyl-removing enzyme (EC 2 .7.7.59) of Escherichia coli and its interaction with the $\mathrm{P}_{\text {II }}$ protein. Biochemistry 37, 12782-12794.

Jiang, P., Peliska, J. A. \& Ninfa, A. J. (1998b). Reconstitution of the signal-transduction bicyclic cascade responsible for the regulation of $n t r$ gene transcription in Escherichia coli. Biochemistry 37, 12795-12801.

Jiang, P., Peliska, J. A. \& Ninfa, A. J. (1998c). The regulation of Escherichia coli glutamine synthetase revisited: role of 2ketoglutarate in the regulation of glutamine synthetase adenylation state. Biochemistry 37, 12802-12810.

Kim, I. H., Kwak, S. J., Kang, J. \& Park, S. C. (1998). Transcriptional control of the $g \ln D$ gene is not dependent on nitrogen availability in Escherichia coli. Mol Cells 8, 483-490.

Lorkiewicz, Z. (1997). Nodulation genes in the Rhizobium-plant signal exchange. Acta Biochim Pol 44, 1-12.

Magasanik, B. (1982). Genetic control in nitrogen assimilation in bacteria. Annu Rev Genet 16, 135-168.

Mangum, J. H., Magni, G. \& Stadtman, E. R. (1973). Regulation of the glutamine synthetase adenylylation and deadenylylation by the enzymatic uridylylation and deadenylylation of the $\mathrm{P}_{\mathrm{II}}$ regulatory protein. Arch Biochem Biophys 158, 514-525.

Maniatis, T., Fritsch, E. F. \& Sambrook, J. (1982). Molecular Cloning: a Laboratory Manual. Cold Spring Harbor, NY: Cold Spring Harbor Laboratory.

Merrick, M. J. \& Edwards, R. A. (1995). Nitrogen control in bacteria. Microbiol Rev 59, 604-622.

Miller, J. (1972). Experiments in Molecular Genetics. Cold Spring Harbor, NY: Cold Spring Harbor Laboratory.

Moreno, S., Patriarca, E. J., Chiurazzi, M., Meza, R., Defez, R., Lamberti, A., Riccio, A., laccarino, M. \& Espin, G. (1992). Phenotype of a Rhizobium leguminosarum ntrC mutant. Res Microbiol 143, 161-171.

O'Connell, K. P., Raffel, S. J., Saville, B. J. \& Handelsman, J. (1998). Mutants of Rhizobium tropici strain CIAT899 that do not induce chlorosis in plants. Microbiology 144, 2607-2617.

Patriarca, E. J., Chiurazzi, M., Manco, G., Riccio, A., Lamberti, A., De Paolis, A., Rossi, M., Defez, R. \& laccarino, M. (1992). Activation of the Rhizobium leguminosarum glnII gene by $\mathrm{NtrC}$ is dependent on upstream DNA sequences. Mol Gen Genet 234, 337-345.

Patriarca, E. J., Riccio, A., Tate, R., Colonna-Romano, S., laccarino, M. \& Defez, R. (1993). The $n t r B C$ genes of Rhizobium leguminosarum are part of a complex operon subject to negative regulation. Mol Microbiol 9, 569-577.

Patriarca, E. J., Tate, R., Fedorova, E., Riccio, A., Defez, R. \& laccarino, M. (1996). Down-regulation of the Rhizobium ntr system in the determinate nodule of Phaseolus vulgaris identifies a specific developmental zone. Mol Plant-Microbe Interact 9, 243-251.

Patschkowski, T., Schlüter, A. \& Priefer, U. B. (1996). Rhizobium leguminosarum bv. viciae contains a second $f n r / f i x K$-like gene and an unusual fixL homologue. Mol Microbiol 21, 267-280.

Priefer, U. B. (1989). Genes involved in lipopolysaccharide production and symbiosis are clustered on the chromosome of Rhizobium leguminosarum biovar viciae VF39. J Bacteriol 171, 6161-6168.

van Rhijn, P. \& Vanderleyden, J. (1995). The Rhizobium-plant symbiosis. Microbiol Rev 59, 124-142.

Schäfer, A., Tauch, A., Jäger, W., Kalinowski, J., Thierbach, G. \& Pühler, A. (1994). Small mobilizable multi-purpose cloning vectors derived from the Escherichia coli plasmids pK18 and pK19: selection of defined deletions in the chromosome of Corynebacterium glutamicum. Gene 145, 69-73.

Schlüter, A., Patschkowski, T., Quandt, J., Selinger, L. B., Weidner, 
S., Krämer, M., Zhou, L., Hynes, M. F. \& Priefer, U. B. (1997). Functional and regulatory analysis of the two copies of the fixNOQP operon of Rhizobium leguminosarum strain VF39. Mol Plant-Microbe Interact 10, 605-616.

Shatters, R. G., Somerville, J. E. \& Kahn, M. L. (1989). Regulation of glutamine synthetase II activity in Rhizobium meliloti 104A14. J Bacteriol 171, 5087-5094.

Shatters, R. G., Liu, Y. \& Kahn, M. L. (1993). Isolation and characterization of a novel glutamine synthetase from Rhizobium meliloti. J Biol Chem 268, 469-475.

Simon, R. (1984). High frequency mobilization of gram-negative bacterial replicons by the in vitro constructed Tn5-Mob transposon. Mol Gen Genet 196, 413-420.

Simon, R., Priefer, U. \& Pühler, A. (1983). A broad host range mobilization system for in vivo genetic engineering: transposon mutagenesis in Gram negative bacteria. Bio/Technology 1, 784-791.
Simon, R., O'Connell, M., Labes, M. \& Pühler, A. (1986). Plasmid vectors for the genetic analysis and manipulation of rhizobia and other gram-negative bacteria. Methods Enzymol 118, 640-659.

Staden, R. (1986). The current status and portability of our sequence handling software. Nucleic Acids Res 14, 217-231.

Udvardi, M. K. \& Day, D. A. (1997). Metabolite transport across symbiotic membranes of legume nodules. Annu Rev Plant Physiol Plant Mol Biol 48, 493-523.

Vieira, J. \& Messing, J. (1982). The pUC plasmids, an M13mp7derived system for insertion mutagenesis and sequencing with synthetic universal primers. Gene 19, 259-268.

Yanisch-Perron, C., Vieira, J. \& Messing, J. (1985). Improved M13 phage cloning vectors and host strains: nucleotide sequences of the M13mp18 and pUC19 vectors. Gene 33, 103-119.

Received 27 July 2000; accepted 14 August 2000. 